\title{
Liderlik Tarzları İle Örgütsel Bă̆lılı Arasındaki İlişkinin Incelenmesine Yönelik Bir Alan Araştırması
}

\author{
Investigation of the Relationship Between Leadership Styles and Organizational \\ Commitment A Field Study \\ Kemalettin ERYEŞIL \\ Rifat IRAZ $Z^{* *}$
}

ÖZ

Bu çalışmanın amacı, banka çalışanlarının liderlik tarzları algıları ile örgütsel bağlılık arasındaki ilişkiyi araştırmaktır. Bu amaç doğrultusunda Konya il merkezindeki 140 banka çalışanı üzerinde anket uygulanmıştır. Anket yöntemi ile elde edilen veriler analiz edilmiştir. Yapılan korelasyon analizi sonuçlarına göre genel olarak çalışanların örgütsel bağlllık ile dönüşümcü liderlik ve yönetsel liderlik algılarl arasında pozitif yönlü ve anlamlı bir ilişki olduğu gözlemlenirken, serbest bırakıcı liderlik algısı ile örgütsel bağlllık düzeyi ve örgütsel băglılı̆̆ın duygusal bağlılık ve normatif bağlılık boyutları açısından negatif yönlü ve istatistiksel bakımdan anlamlı olmayan bir ilişki tespit edilmiştir.

\author{
ANAHTAR KELIMELER \\ Lider, Liderlik, Liderlik Tarzlarl, Örgütsel Băğllık
}

\begin{abstract}
The aim of this study is to investigate the relationship between bank employees' perceptions of leadership styles and organizational commitment. For this purpose, a survey was conducted among 140 bank employees in the city center of Konya. The data which was obtained by survey method was analyzed. According to the correlation analysis, while it is observed that there is generally a positive and significant relationship between organizational commitment of employees and transformational and managerial leadership; negative and statistically insignificant relationship is found in terms of laissez-faire leadership perception and level of organizational commitment, and emotional commitment and normative commitment dimensions of organizational commitment.
\end{abstract}

\section{KEYWORDS}

Leader, Leadership, Leadership Styles, Organizational Commitment.

\footnotetext{
*** Bu çalışma, danışmanlığı Doç. Dr. Rifat İraz tarafından yapılan “Liderlik Tarzları ile Örgütsel Bağııık Arasındaki ilişskinin Incelenmesine Yönelik Bir Alan Araştırması" başlıklı yüksek lisans tezinden türetilmiştir. 


\section{GíRiș}

Rekabetin arttığı ve teknolojik değişmelerin hız kazandığı bir çevrede faaliyet gösteren işletmelerin günümüz rekabetçi koşullarında ayakta kalabilmeleri ve yaşamlarını sürdürebilmeleri gittikçe zorlaşmakta ve varlıklarını devam ettirebilmeleri sürdürülebilir rekabet üstünlüğü sağlayabilmelerine bağlı olmaktadır. Dinamik bir yapı içerisinde bulunan işletmelerin rekabet avantajı elde edebilmeleri ve hem iç hem de dış çevrelerindeki değişimlere uyum sağlayabilmeleri değişime ayak uydurabilecek çalışanlar aracilığıyla gerçekleşecektir. Dolayısıyla, çalışanların örgütün hedeflerini benimsemesi, bu hedefler doğrultusunda gerçekleştirecekleri faaliyetleri yerine getirme konusundaki çabalarında istekli olmaları ve bu çabalarındaki isteklerinin devamlılık arz etmesi yani çalışanların örgütsel bağgl1lğı işletmeler için büyük önem taşımaktadır. Bu süreç doğrultusunda çalışanları örgütün bir parçası haline getirecek ve örgütsel hedefler doğrultusunda yönlendirecek liderlere duyulan gereksinim artmaktadır. Dolayısıyla günümüz örgütlerinin başarılı olabilmesi ve varlığını devam ettirebilmesi için klasik liderlik yaklaşımlarının yanı sıra çağdaş liderlik yaklaşımlarının benimsenmesi gerekliliği ortaya çıkmıştır.

Liderler, sahip oldukları özellikleri, yönetme ve yöneltme becerileri ve yöntemleri ile çalışanların örgütsel bağlılığını artırabilecek ve çalışanların bağlılığını artırabilecek kişilerdir. Banka çalışanlarının örgütsel bağlılığını etkileyen temel faktörlerden birisi de yöneticilerin sergiledikleri liderlik davranışlarıdır. Bu varsayımdan hareketle bu çalışmanın amacı, banka çalışanlarının liderlik tarzları algıları ile örgütsel bağlılık arasındaki ilişkiyi ortaya koymaktır. Bu bağlamda bu çalışmada, banka çalışanlarının liderlik tarzları algıları ile örgütsel bağlılık arasındaki ilişki tespit edilmeye çalışılacaktır. Bu kapsamda, Konya ilinde bankacılık sektöründeki çalışanlar üzerinde yapılan araştırmaya ve bu araştırma sonuçlarına yer verilecektir.

\section{KURAMSAL ÇERÇEVE}

\subsection{LIDERLİK KAVRAMI}

İnsanların toplumsal, örgütsel, ekonomik ve siyasal yaşamında önemli bir yer tutan liderlik, çok çalışılan ve tartışılan bir konu olmasına rağmen farklı yazarlar ve araştırmacılarca, farklı bilim dallarında, değişik açılardan yapılan farklı tanımlamaları bulunmakla beraber, üstünde uzlaşılmaya varılmış tek bir liderlik tanımı bulunmamaktadır (Bakan, 2009:140).

Liderlik kavramı, örgütsel davranış, yönetim bilimi ve işletme yönetimi alanında araştırma yapan bilim adamlarının çok yoğun olarak çalıştıkları bir konu olmuştur. Liderlikle ilgili 3000'den fazla ampirik araştırma yapılmıştır (Çelik, 2000: 1). Araştırmacılar, genellikle liderliği daha çok sahip oldukları perspektiflere, ilgi duydukları ve önemli gördükleri olgulara göre tanımlamıştır. Stodgill'in liderlikle ilgili yapmış olduğu kapsamlı bir literatür taramasından sonra "liderlik kavramını tanımlamaya çalışan kişi kadar liderliğin tanımı olduğunu" gözlemlemiştir. Stodgill'in yaptığı gözlemden bu yana liderlikle ilgili yeni tanımların yapılmasına devam edilmiştir. Liderlik kavramı ile ilgili son 50 yıl içinde yapılan tanımlardan bazıları aşağıdaki gibi sıralanabilir (Yukl, 2010: 2):

- Liderlik (leadership) kavramının kökeni İngilizce olup kavramın aslı fiil olarak "lead" şeklindedir. Liderlik kavramının anlamı; yön göstermek, yol göstermek, kılavuzluk etmek, öncülük etmek ve rehberlik yapmaktır. "Leader" ise; rehber, kılavuz, önder, baş ve lider anlamları taşımaktadır. Liderlik kavramının Türkçedeki karşılığı önderlik kelimesi olarak önerilmişse de ulusal literatürde "liderlik" kelimesi daha yaygın olarak kabul görmekte ve kullanılmaktadır (Şişman, 2002: 2).

- Werner'e göre (1993) ise liderlik, belli bir durumda belli bir zamanda ve belli koşullar altında bir gruptaki üyelerin örgütsel hedeflerine ulaşması için çabalamasını teşvik eden, ortak amaçlara ulaşmada yardımcı olan, deneyimleri aktaran ve uygulanan liderlik tarzından memnun olmalarını sağlayan etkileme sürecidir (Werner, 1993: 17).

- Hodgetts'e göre (1999) liderlik, belli amaçlara ulaşma amacıyla insanların çabalarını yönlendirme ve etkileme süreci olarak tanımlamaktadır (Hodgetts, 1999: 534).

- Cooper' a göre (2003) liderlik, esas olarak belirli bir amaca yönelik olarak grup üyelerinin çabalarını planlama, motive etme ve kontrol etme işidir (Cooper, 2003: 17).

- George ve Jones (2008) liderliği, grup üyelerinden birinin örgütsel amaçlara ulaşmak için diğer grup üyelerini etkilemesi olarak tanımlamaktadır (George ve Jones, 2008: 391).

- Yukl'a göre (2010) liderlik, grup üyelerinden birinin grup faaliyetlerini örgütsel amaçların gerçekleştirilmesi doğrultusunda koordine etmesi ya da yönlendirmesi sürecidir (Yukl, 2010: 3).

Görüldüğü üzere tanımların birleştiği noktalar genel olarak aynıdır. Ortak payda konumundaki kriterler; belli bir amacın olması, belli koşulların olması, belli bir grubun izleyicilerinin olması ve bu grubu 
yönlendirebilecek bir liderin bulunmasıdır. Bu doğrultuda " liderlik; bir grup insanı, belirli koşullar altında, belirli amaçlar etrafında toplayabilme ve bu amaçları gerçekleştirmek için onları harekete geçirme, etkileyebilme bilgi ve yeteneklerinin toplamıdır" şeklinde bir tanım yapılabilir (Zel, 2006: 110).

\subsubsection{LIDERLİK TARZLARI}

Küreselleşmenin getirdiği rekabet ortamının daha belirgin hale geldiği günümüzde, yöneticiler ile çalışanların beklenti ve istekleri liderlik alanında da yeni yaklaşımların ortaya çıkmasına neden olmuştur. Temel olarak onbir farklı liderlik yaklaşımı bulunmaktadır.

\subsubsection{Demokratik Liderlik}

Demokratik liderlikte; lider astlarına danışarak onların planlama, karar verme ve örgütlenme faaliyetlerine katılmalarını teşvik eder. Başka bir ifadeyle, lider astlarının karar verme sürecinin bir parçası olmaları için cesaretlendirir. Ayrıca, çalışanlar yaptıkları işi etkileyen durumlar hakkında bilgilendirilmekte, fikirlerini ve görüşlerini söyleyerek öneriler getirmeleri için lider tarafından cesaretlendirilmektedir (http://www.pearsonschoolsandfecolleges.co.uk.).

\subsubsection{Otokratik Liderlik}

Otokratik liderlik, bürokratik toplumlarda yetişip bu eğitimi alan ve belli bir birikime sahip insanlar için uygun bir liderlik tarzdır. Liderler veya yöneticiler, çalışanların veya astların duygularını ve düşüncelerini çok fazla dikkate almadıkları için iş tatminsizliği maksimum, örgüte olan bağlılık minimum düzeydedir. Otokratik lider davranış biçiminde yetki, merkezde toplandığı için karar alma süreci çok hızlıdır. Başka bir ifadeyle, Otokratik liderler otoritelerini ve sorumluluklarını devretmeden bütün kararları kendileri alır, astların karar verme sürecine katılmalarına izin vermezler (Serinkan, 2008: 156).

\subsubsection{Tam Serbesti Tanıyan Liderlik}

Tam serbesti tanıyan liderlikte; lider, astların kendi amaçlarını kendilerinin belirlemesini ve her izleyicinin kendisine verilen kaynaklar dâhilinde amaç, plan ve programlarını yapmalarına olanak tanıyan ve astların kendi kararlarını kendilerinin vermesini temel alır. Mesleki uzmanlık durumlarında ve bilim adamlarının çalışmalarında, işletmelerin araştırma geliştirme departmanlarında çalışan yüksek bilgi, tecrübe ve uzmanlığa sahip elemanların yaratıcı ve yenilikçi fikirler geliştirmelerinde bu tip bir liderlik uygulanabilir (Eren, 2008: 459; Yörük vd., 2011: 105).

\subsubsection{Destekleyici Liderlik}

Destekleyici liderlikte; liderin davranışı sempatik, dostça ve astların gereksinimlerini karşılamaya yönelik bir davranış olarak kabul edilir (Ogbonna ve Harris, 2000; Bakan, 2009: 142). Lider kararları grup üyeleri ile birlikte almaz. Ancak onların görüş ve önerilerini alarak karar alır. Katılım ve ödül sistemlerini uygular. Aşağıdan yukarıya, yukarıdan aşağıya olmak üzere iki yönlü bilgi akışına açıktır. Örgütsel amaçlar örgüt üyelerine danışıldıktan sonra belirlenir ve emirlerle üyelere ulaştırılır (Sabuncuoğlu ve Tüz, 2001: 218).

\subsubsection{Vizyoner Liderlik}

Vizyoner lider, vizyoner tarzda davranan kişidir. Bu tarzdaki liderler, etkili olmak için belirsiz verileri başarılı bir şekilde analiz edebilme ve çözümlemelerine olanak veren düşünme gücüne sahip ve problemleri yenerek firsatları artırabilecek düşünceler yaratabilen kişilerdir. Bununla birlikte, vizyoner liderlerin tutarlı olarak çevresinde alternatif yaklaşımlar arayan kişi olması beklenmektedir (Doğan, 2007: 97).

\subsubsection{Hümanist Liderlik}

Hümanist liderin en belirgin özelliği babacan (patrimonial) davranışlarının olması yani korumacı rolünde olmasıdır. Bu yaklaşımda lider, zaman zaman orta basamaktakilerin fikrini alır. Duygusal yönlendirmeyle motive eder. Ödül sistemini ağırlıklı olarak kullanır ve zorunluluk olmadıkça cezalandırmaya gitmez (Şimşek vd., 2011: 246).

\subsubsection{Otantik Liderlik}

Otantik liderler, kim olduklarını, neye inandıklarını bilirler ve bu değerler ile inançlar doğrultusunda hareket ederler. Destekçileri liderlerini etik kişiler olarak görürler. Bu nedenle otantik liderliğin temel sonucu güvendir. Otantik liderler bilgi paylaşır, açık iletişımi teşvik eder ve ideallerine sıkı sıkıya bağlıdırlar (Robbins ve Judge, 2012: 394). 


\subsubsection{Hizmetkâr Liderlik}

1970 yılında Robert Greenleaf "hizmet edici liderlik" kavramını ortaya atmış ve 1977 yılında yayınladığı kitabın adı olmuştur. Greenleaf' a göre, hizmetkâr liderliğin özü ve öncelikli sorumluluğu astlara ve örgütüne hizmet etmektir. Buradaki "hizmet etme" kavramından anlaşılması gereken, astların geliştirilmesi, savunulması ve yetki ile güçlendirilmeleridir. Hizmet eden bir lider astlarının ihtiyaçlarına daha duyarlı olmalı ve daha sağlıklı, daha akıllı ve sorumluluk almaya daha fazla istekli hale gelebilmeleri için onlara yardımcı olmalıdır. Bu tür bir lider, organizasyonun finansal çıkarına uygun olmasa bile, iyiyi ve doğruluğu temsil etmeli ve gerektiğinde sosyal anlamdaki adaletsizlik ve eşitliksizliklere karşı gelebilmelidir (Güney, 2006: 141; Yukl, 2010: 419).

\subsubsection{Karizmatik Liderlik}

Karizmatik liderler kendilerine oldukça fazla güvenen, takipçilerine karşı duyarlı olan, ileriyi gören, vizyonlarını açıkça belirten ve bulunduğu ortamda ihtiyaç duyulan etkileyici güce sahip kişilerdir. Karizmatik lideri diğerlerinden farklı kılan; sahip olduğu öngörü, vizyon, durumu net ve çok boyutlu bir şekilde değerlendirebilme, inandığı değerleri benimsetebilme, insanları inandığı amaca ulaştırabilme ve radikal değişiklikler için harekete geçirebilme yeteneğidir. Bu tarz liderler genellikle, geçiş ya da kriz zamanlarında ortaya çıkmaktadırlar. Çünkü bu liderlikte yetki tamamen kendiliğinden kazanılmaktadır (Saruhan ve Yıldız, 2009: 249).

\subsubsection{Transformasyonel (Dönüşümcü) Liderlik}

Transformasyonel liderlik, örgütte ani ve etkili değişimi geliştirmeye yönelik bir liderlik tarzıdır. Etkin olarak değişimi başlatma, bu değişime rehberlik edecek ileri görüşlülük oluşturma ve bu değişim için gerekli olan ihtiyacı tanımlamada lidere imkân tanıyacak yeteneklerin bir birleşimidir. Başka bir tanımında ise Transformasyonel liderlik, liderin çalışanlarca güvenilir kabul edilmesi gerektiğinin önemine değinerek dönüşümcü lideri örgüt için tanımlanabilir bir vizyon belirleyen kişi olarak tanımlanmaktadır (Bass, 1990: 19).

Transformasyonel liderler, “İdeal Etki/Karizma, İdeal Davranışlar, Telkin Edici Motivasyon, Bireysel Düzeyde Illgi ve Zihinsel Teşvik” olmak üzere beş farklı yönetim tarzı sergilemektedirler (Saruhan ve Yıldız, 2009: 248):

\subsubsection{Transaksiyonel (Etkileşimci) Liderlik}

Transaksiyonel liderlikte lider, astlarının kişisel değerlerini geliştirmek ya da kendisine güvenmelerini sağlamak için bir çaba harcamaktansa astlarının ihtiyaçlarını göz önüne almakta ve astları önceden belirlenen performans seviyesine ulaştı̆̆ında o ihtiyaçları tatmin etmeye çalışmaktadır (Jung ve Avolio, 2000: 950).

Transaksiyonel liderlik, liderin astlarına ödüller sunduğu ve bunun karşıllğında da astlarının performanslarını ve çabalarını aldığı bir değiş-tokuş sürecine dayanmaktadır (Pillai vd., 1999: 898). Başka bir deyişle etkileşimci liderlik, yöneticilerin çalışanlarını açık ve net bir şekilde belirlenmiş görev tanımlamaları ile motive ettiği ve çalışanların amaçlara ulaşmadaki çabalarına göre ödüllendirildiği bir yaklaşım tarzıdır (Doğan, 2007: 75).

Transaksiyonel liderler, "koşullu ödüllendirme, aktif olarak istisnalarla yönetim ve pasif olarak istisnalarla yönetim" olmak üzere üç farklı yönetim tarzı sergilemektedirler (Şimşek vd., 2011: 247):

\section{2.ÖRGÜTSEL BAĞLILIK}

Örgütsel bağl1lık konusu ile ilgili örgütsel psikoloji, örgütsel davranış ve sosyal psikoloji gibi farklı disiplinlerin ilgisinin giderek artması, bu alanlardan gelen araştırmacıların konuya kendi bakış açılarını getirmeleri, örgütsel bağlılık kavramının anlaşılmasını güçleştirmektedir. Bu yüzden örgütsel bağlık kavramı ile ilgili üzerinde görüş birliğine varılmış bir tanım bulunmamaktadır. Morrow literatürde örgütsel bağl1lıkla ilgili yirmi beşin üzerinde farklı tanımın bulunduğunu belirtmektedir. Bu farklılık, örgütsel bağl1l1k kavramının tanımlanmasına yansımakta ve farklı tanımların ortaya çıkmasına sebep olmaktadır. Bu tanımlardan bazıları aşağıda verilmektedir (Gül, 2002: 38):

- Meyer ve Allen (1991) örgütsel bağl1lı̆̆1 psikolojik bir boyuta sahip olan, iş görenlerin örgütle ilişkisi ile şekillenen ve örgütün sürekli bir üyesi olma kararı almalarını sağlayan bir davranış olarak tanımlamaktadırlar (Meyer ve Allen, 1991: 67).

- Yüksel (2000) örgütsel bağlılı̆̆1, yalnızca işverene sadakat süreci değil, örgütün iyiliği ve başarısının sürekliliği için örgüte dahil olanların düşüncelerini açıklayıp, çaba gösterdikleri bir süreç olarak tanımlamaktadır (Bayram, 2005: 128). 
- Porter, Steers ve Mowday örgütsel bağl1lı̆̆1; bireylerin örgütle özdeşleşmeleri, örgütsel amaç ve değerler yönünde çaba sarf etmeleri olarak tanımlamaktadırlar (Paulin vd., 2006: 908; Çöl, 2004).

- Yiing ve Ahmad' a göre (2009) örgütsel bağl1lık, bir çalışanın örgütün amaç ve değerlerine olan inanc1, sadakati ve örgütün bir üyesi olarak kalma arzusunu ifade etmektedir (Yiing ve Ahmad, 2009: 56).

- Barnard' a göre genel anlamda örgütsel bağl1lık, çalışanın örgütüne psikolojik olarak bağlanmasını ifade etmektedir (Sharma ve Bajpai, 2010: 9).

Bütün bu tanımlardan hareketle örgütsel bağlılık kavramının tanımını; çalışanların örgütte kalmak istemeleri, örgütün tüm etkinliği, çıkarı ve başarısı ile özdeşleşmeleri, çalışanın örgüte karşı olan sadakati, tutumu ve çalıştığı örgütün başarılı olabilmesi için gösterdiği ilgi şeklinde özetlememiz mümkün olabilecektir (Bayram, 2005: 128). Mowday ve arkadaşları 1979 yılında yaptıkları çalışmada örgütsel bağl1lı̆̆ tanımlayan üç temel unsurun bulunduğunu ifade etmişlerdir. Bu unsurlar (Eisenberg vd., 1987:181; Tannenbaum vd., 1991: 759-760; Yousef, 2003: 1068; Wright ve Kehoe, 2007: 8; Boylu vd., 2007: 58; WeiBo vd., 2010: 13):

- Örgütün amaç ve değerlerini benimseme ve bu değerlere karşı güçlü bir inanç hissetme,

- Örgüt yararı ve sürekliliği için beklenenden daha fazla çaba harcama,

- Örgüt üyeliğini devam ettirmek için güçlü bir istek ve arzu duymadır.

Örgütsel bağlılık kavramı ile ilgili yapılan tanımların ortak özellikleri örgüte bağlanan bireylerin örgüt başarısı için ellerinden gelen katkıları sağlama doğrultusunda davranış gösterecekleri beklentisidir. Aynı zamanda bağl1lıkları güçlü olan çalışanların performans düzeylerinin bağl1lık duymayan çalışanlara göre daha yüksek olacağı düşüncesi örgütsel bağlılık kavramının tanımlanmasında temel alınan en önemli unsur olmaktadır (Özler, 2010: 3).

Literatürde örgütsel bağlılık konusunda çeşitli yaklaşımlara rastlanmaktadır. Örgütsel bağl1lık ile ilgili olarak Meyer ve Allen tarafından geliştirilen çok boyutlu örgütsel bağl1lık modeli, araştırmacılar tarafından kabul görmüş ve örgütsel bağlılık çalışmalarında sıklıkla kullanılan bir model olarak bilinmektedir. Bu nedenle çalışmada, araştırmanın amacına yönelik olarak tutumsal bağlılık yaklaşımı içerisinde yer alan Meyer ve Allen tarafından geliştirilen sınıflandırma üzerinde durulmuştur (Çekmecelioğlu, 2006: 155; Albayrak, 2007: 48-49).

Meyer ve Allen örgütsel bağl1lı̆̆1; duygusal (affective) bağl1lık, devam (continuence) bağl1lı̆̆ ve normatif (normative) bağl1lık olarak sinıflamıştır ( Meyer ve Allen, 1991: 61-89). Duygusal bağlllık, işletmede çalışan bireylerin duygusal olarak kendi tercihleri ile işletmede kalma isteği olarak tanımlanmıştır. Devamlılık bağlllığı, çalışanların işletmeden ayrılmanın beraberinde getireceği maliyeti dolayısıyla olumsuzlukları dikkate alması ve bir zorunluluk olarak işletmede devam etmesi olarak tanımlanmıştır. Normatif bağlllık ise, işletmede çalışanların ahlaki bir görev duygusuyla ve işletmeden ayrılmama gerektiğine inandıkları için kendilerini örgüte bağlı hissetmeleri olarak ifade edilmiştir (Meyer ve Allen, 1997: 11). Başka bir deyişle, duygusal bağl1lığ 1 yüksek olan çalışanlar istedikleri için, devam bağl1lı̆̆ yüksek olan çalışanlar ihtiyaç duydukları için de son olarak normatif bağl1lıkları fazla olan çalışanlar ise yükümlülüklerinden dolayı örgütlerindeki üyeliklerine devam ederler (Güney, 2011: 289). Bu üç bağl1k türünün (duygusal, devamlılık ve normatif) ortak yanı, iş görenleri bir örgüte bağlayan ve onların örgütle olan beraberliğinin devam edip etmeyeceği kararlarını etkileyen bir psikolojik durumu yansıtmasıdır (Meyer, Allen and Smith, 1993: 539; Obeng ve Ugboro, 2003: 84).

Sonuç olarak; örgütsel bağlılığın yüksek olmasının çalışanların performansını, iş tatminini, örgütsel verimliliğini artırdığı; işe devamsızlığı ve geç kalmayı, işten ayrılmayı yani personel devir hızını azalttığı birçok araştırmacı tarafından çeşitli çalışmalarda ortaya konmuştur (Ferris ve Aranya, 1983; Üner vd., 1998; Guatam vd., 2004; Mathieu ve Zajac, 1990:171-172).

\section{ARAȘTIRMANIN METODOLOJISI}

Çalışmanın bu bölümünde anket yöntemi kullanılarak gerçekleştirilen araştırmanın amacı, hipotezleri, yöntemi ve bulguları hakkında bilgi verilecektir. Ayrıca, araştırmada elde edilen sonuçların istatistiksel bakımdan anlamlı olup olmadıkları değerlendirilecek ve hipotezlerin doğrulanıp doğrulanmadığı sinanacaktır.

\subsection{Araştırmanın Yöntemi ve Örneklem}

Bu çalışmanın veri setinin oluşturulmasında anket yönteminden yararlanılmış olup araştırma Konya ilinde faaliyet gösteren bankalardaki çalışanlar üzerinde yürütülmüştür. Çalışmada veriler likert ölçeği dikkate 
alınarak hazırlanan standart bir anket formu aracılığıyla cevaplayıcılarla yüz yüze yapılan görüşmelerle toplanmıştır. Ölçeklerdeki maddeler ' 1 '='kesinlikle katılmıyorum' ve ' 5 '='kesinlikle katılıyorum' şeklinde siralanmıştır.

Araştırmada çalışanların liderlik algılarını ölçmek için $1985^{\circ}$ de ilk kez Bass tarafından geliştirilmiş olup daha sonraki çalışmalar ile revize edilmiş ve Bass ve Avalio (1999) tarafindan son şeklini (MLQ Form 5x) verilerek güncellenen "Çok Faktörlü Liderlik Anketi” (Multi Factor Leadership Questionairre/MLQ)'nin bir kısmından faydalanılmıştır. Örgütsel bağlılık ise Allen ve Meyer (1991) tarafından geliştirilen "Çok Boyutlu Örgütsel Bağlılık Ölçeği” kullanılarak ölçülmüştür.

Araştırma Konya il merkezinde faaliyette bulunan bankalarda görev yapmakta olan farklı pozisyonlarda çalışan banka çalışanları üzerinde yapılmıştır. 2011 yılı itibariyle Türkiye Bankalar Birliği’nin yayınladığı istatistiki verilere göre Konya ilinde faaliyet gösteren bankalarda 2703 kişi çalışmaktadır. Örnek kütlenin seçiminde belirtilen bu rakam Konya il merkezi ve ilçelerini kapsamaktadır. Araştırmanın ana kütlesini Konya il merkezinde faaliyet gösteren banka şubelerinde çalışan kişiler oluşturduğu için ana kütlenin yaklaşık olarak 1500 kişi olduğu tahmin edilmektedir. Bu bilgiler doğrultusunda Konya il merkezinde çalışan 180 kişiye kolayda örnekleme yoluyla anket uygulaması yapılmıştır. Uygulanan 180 anketten geri gelen 165 anketin 25 tanesi çeşitli nedenlerle değerlendirilme dışı bırakılarak 140 adet anket değerlendirilmeye alınmıştır.

\subsection{Araştırmanın Amacı ve Hipotezleri}

Araştırmanın temel amacı; Konya il merkezinde faaliyet gösteren bankalardaki çalışanların liderlik tarzı algıları ve örgütsel bağlılıklarını belirlemek, bununla birlikte araştırma kapsamında çalışanların liderlik tarzı algıları ve örgütsel bağlılık düzeylerinde farklılık olup olmadığını tespit edilmesidir.

Konya il merkezinde faaliyet gösteren bankalarda çalışanların liderlik tarzı algıları ile örgütsel bağl1lık düzeyleri arasındaki ilişkiyi belirlemeye yönelik yapılan araştırma kapsamında geliştirilen hipotez aşağıda belirtilmiştir.

$\mathbf{H}_{1}$ : Banka çalışanlarının örgütsel bağlılık düzeyleri ile liderlik tarzları algıları arasında pozitif ve anlamlı bir ilişki vardır.

\section{ARAŞTIRMANIN BULGULARI}

Araştırma kapsamında ankete katılan banka çalışanlarının demografik özelliklerine ilişkin bulgular Tablo3.1'de belirtilmiştir.

Tablo 3.1. Örneklemin Demografik Özellikleri

\begin{tabular}{|c|c|c|c|c|c|}
\hline Özellikler & $\mathbf{F}$ & & Özellikler & & \\
\hline Cinsiyet & & & Çalışma Süresi & & \\
\hline Erkek & 81 & 57,9 & 1 yıldan az & 10 & 7,1 \\
\hline Kadın & 59 & 42,1 & $2-4$ yıl arası & 45 & 32,1 \\
\hline Yaş & & & $5-10$ yıl arası & 51 & 36,4 \\
\hline 18-27 yaş arası & 45 & 32,1 & $10-20$ yıl arası & 24 & 17,1 \\
\hline $28-37$ yaş arası & 74 & 52,9 & 20 yıl ve üzeri & 10 & 7,1 \\
\hline $38-47$ yaş arası & 18 & 12,9 & & & \\
\hline 48 yaş ve üzeri & 3 & 2,1 & & & \\
\hline Eğitim Durumu & & & İşletmede Çalıştığı Birim & & \\
\hline Lise & 13 & 9,3 & Operasyon & 61 & 43,6 \\
\hline Önlisans & 24 & 17,1 & Bireysel Krediler & 37 & 26,4 \\
\hline Lisans & 87 & 62,1 & Tarımsal Krediler & 5 & 3,6 \\
\hline \multirow[t]{7}{*}{ Lisansüstü } & 16 & 11,4 & Ticari Krediler & 28 & 20,0 \\
\hline & & & $\begin{array}{l}\text { Diğer } \\
\text { Unvan }\end{array}$ & 9 & 6,4 \\
\hline & & & Servis Görevlisi & 48 & 34,3 \\
\hline & & & Servis Yetkilisi & 47 & 33,6 \\
\hline & & & Yönetmen Yardımcısı & 24 & 17,1 \\
\hline & & & Yönetmen & 20 & 14,3 \\
\hline & & & Şube Müdürü & 1 & 0,7 \\
\hline Toplam & 140 & 100 & Tonlam & 140 & 100 \\
\hline
\end{tabular}


Ankete katılan banka çalışanlarının demografik değişkenlerine ilişkin sonuçlar incelendiğinde çalışanların çoğunluğunun erkek $(\% 57,9), 28-37$ yaş arasında $(\% 52,9)$, eğitim durumunun genel olarak lisans düzeyinde $(\% 62,1)$ olduğu anlaşılmaktadır. Çalışanların çalıştıkları bankada çalışma süreleri incelendiğinde genellikle 5-10 yıl arasında $(\% 30,7)$ olduğu ve çalışma yıllarının ise genel olarak 5-10 yıl arasında $(\% 36,4)$ olduğu gözlemlenmektedir. Ayrıca ankete katılan banka çalışanlarının genellikle servis görevlisi $(\% 34,3)$ ve servis yetkilisi $(33,6)$ pozisyonlarında çalıştığı görülmektedir.

Tablo 3.2. Kullanılan Ölçeklerin Güvenilirlik Analizi Sonuçları

\begin{tabular}{|c|c|c|c|c|}
\hline Ölçekler & Boyutlar & $\begin{array}{l}\text { İfade } \\
\text { SayısI }\end{array}$ & Cronbach's & \\
\hline \multirow{5}{*}{ Dönüşümcü Liderlik } & Aktif İdealleştirilmiş Etki & 4 & 0,785 & \multirow{5}{*}{0,938} \\
\hline & Pasif İdealleştirilmiș Etki & 4 & 0,631 & \\
\hline & İlham Motivasyon & 4 & 0,799 & \\
\hline & Entelektüel Teşvik & 4 & 0,780 & \\
\hline & Bireye Sayg1 & 4 & 0,775 & \\
\hline \multirow{3}{*}{ Yönetsel Liderlik } & Koşulsal Ödüllendirme & 4 & 0,800 & \multirow{3}{*}{0,880} \\
\hline & İstisnai Yönetim-Aktif & 4 & 0,764 & \\
\hline & İstisnai Yönetim-Pasif & 4 & 0,782 & \\
\hline Serbest Bırakıcı Liderlik & & 4 & & 0,718 \\
\hline \multirow{3}{*}{ Örgütsel Bağl1lık } & Duygusal & 5 & 0,871 & \multirow{3}{*}{0,914} \\
\hline & Normatif & 5 & 0,800 & \\
\hline & Devam & 6 & 0,778 & \\
\hline
\end{tabular}

Tablo 3.2.'de belirtildiği üzere Dönüşümcü Liderlik boyutu $(0,938)$ ve alt bileşenlerini oluşturan Aktif İdealleştirilmiş Etki $(0,785)$, Pasif İdealleştirilmiş Etki $(0,631)$, İlham Motivasyon $(0,799)$, Entelektüel Teşvik $(0,780)$, Bireye Sayg1 $(0,775)$ bileşenlerinin yüksek derecede güvenilir olduğu gözlemlenmiştir. Yönetsel Liderlik $(0,880)$ boyutu ve Koşulsal Ödüllendirme $(0,800)$, İstisnai Yönetim-Aktif $(0,764)$, İstisnai Yönetim-Pasif $(0,782)$ alt bileşenlerinin de yüksek derecede güvenilir olduğu sonucuna ulaşılmıştır. Liderlik tarzlarının son boyutunda ise serbest bırakıcı liderlik boyutunun da güvenilirlik katsayısı $(0,718)$ olduğu gözlemlenmektedir.

Örgütsel bağl1lık $(0,914)$ ve alt boyutlarını oluşturan duygusal bağl1lık $(0,871)$, normatif bağl11ık $(0,800)$ ve devam bağl1lı̆̆ının $(0,778)$ da ölçeklerinin yüksek düzeyde $(\alpha>0,70)$ güvenilir olduğu anlaşılmaktadır. Sonuç olarak ölçeklerin tamamı kabul edilebilir sınırın $(0,70)$ üzerinde ve güvenilir durumdadır.

Tablo 3.3. Katılımcıların Liderlik Tarzları Algılarına İlişkin Bulguların Tanımlayıcı İstatistikleri

\begin{tabular}{|c|c|c|c|c|c|}
\hline Ölçekler & Boyutlar & Ort. & St. Sapma & $\begin{array}{c}\text { Genel } \\
\text { Ort. }\end{array}$ & $\begin{array}{c}\text { Genel St. } \\
\text { Sapma }\end{array}$ \\
\hline \multirow{5}{*}{$\begin{array}{l}\text { Dönüşümcü } \\
\text { Liderlik }\end{array}$} & Aktif İdealleştirilmiş Etki & 3,26 & 0,79 & \multirow{5}{*}{3,35} & \multirow{5}{*}{0,71} \\
\hline & Pasif İdealleştirilmiş Etki & 3,32 & 0,68 & & \\
\hline & İlham Motivasyon & 3,40 & 0,81 & & \\
\hline & Entelektüel Teşvik & 3,39 & 0,80 & & \\
\hline & Bireye Saygı & 3,34 & 0,79 & & \\
\hline \multirow{3}{*}{ Yönetsel Liderlik } & Koşulsal Ödüllendirme & 3,45 & 0,82 & \multirow{3}{*}{3,16} & \multirow{3}{*}{0,49} \\
\hline & İstisnai Yönetim-Aktif & 3,29 & 0,85 & & \\
\hline & İstisnai Yönetim-Pasif & 2,73 & 0,73 & & \\
\hline $\begin{array}{l}\text { Serbest Bırakıc1 } \\
\text { Liderlik }\end{array}$ & & & & 2,47 & 0,81 \\
\hline
\end{tabular}

Notlar: (i) n=140, (ii) Ölçekte $1=$ Kesinlikle Katılmıyorum ve $5=$ Kesinlikle Katıliyorum anlamındadır. (iii) Friedman çift yönlü Anova testine göre $\left(\chi^{2}=20,339 ; p<0,001\right)$ sonuçlar istatistiksel bakımdan anlamlıdır.

Ankete katılan banka çalışanlarının liderlik algılarına yönelik bulgular incelendiğinde Dönüşümcü Liderlik boyutu $(3,35)$ ve alt bileşenlerini oluşturan Aktif İdealleştirilmiş Etki $(3,26)$, Pasif İdealleştirilmiş 
Etki $(3,32)$, İlham Motivasyon $(3,40)$, Entelektüel Teşvik $(3,39)$, Bireye Sayg1 $(3,34)$ bileşenlerinin ortalama değerlerinin yüksek olduğu gözlemlenmektedir. Yönetsel Liderlik $(3,16)$ boyutu ve Koşulsal Ödüllendirme $(3,45)$, İstisnai Yönetim-Aktif $(3,29)$ bileşenlerinin ortalama değerleri yüksek iken İstisnai Yönetim-Pasif $(2,73)$ alt bileşeninin ortalama değeri düşük olduğu gözlemlenmiştir. Liderlik tarzlarının son boyutunda ise serbest bırakıcı liderlik boyutunun da ortalama değeri $(2,47)$ olduğu gözlemlenmektedir. Bu sonuçlar dikkate alındığında banka çalışanlarının liderlerinin çalışanlara serbestlik tanımadığı ancak kararların alımında pasif değil aktif rol oynadığı, liderin astlarını sürekli olarak gözetim altında tuttuğu sonucuna ulaşılabilir.

Tablo 3.4. Katılımcıların Örgütsel Bağlılığa İlişkin Bulguların Tanımlayıcı İstatistikleri

\begin{tabular}{|c|c|c|c|c|c|}
\hline & Boyutlar & Ort. & St. Sapma & Genel Ort. & Genel St. Sapma \\
\hline \multirow{2}{*}{$\begin{array}{c}\text { Örgütsel } \\
\text { Bağlılık }\end{array}$} & Duygusal Bağlılık & 3,15 & 0,95 & \multirow{2}{*}{2} & \multirow{2}{*}{0,80} \\
\cline { 2 - 4 } & Normatif Bağlılık & 2,88 & 0,93 & \\
\cline { 2 - 4 } & Devam Bağlı̆ı̆̆ & 2,80 & 0,83 & & \\
\hline
\end{tabular}

Tablo 3.4. incelendiğinde ankete katılan banka çalışanlarının genel olarak örgüte bağl1lıklarının düşük düzeyde $(2,93)$ olduğu gözlemlenmiştir. Ancak örgütsel bağlılığın alt boyutları dikkate alındığında normatif bağgl11k $(2,88)$ ve devam bağlılığının $(2,80)$ düşük düzeyde olduğu sonucuna ulaşılırken duygusal bağlılık $(3,15)$ düzeylerinin yüksek olduğu sonucuna ulaşılmıştır. Bu sonuçlara göre banka çalışanlarının duygusal olarak çalıştıkları kurum olan bankaya bağlı oldukları söylenebilmektedir.

Tablo 3.5. Liderlik Tarzları Algıları İle Örgütsel Bağlılık Arasındaki İlişki

\begin{tabular}{|c|c|c|c|c|}
\hline & & Dönüşümcü Liderlik & Yönetsel Liderlik & Serbest Bırakıcı Liderlik \\
\hline \multirow{2}{*}{ Örgütsel Bağlılık } & Korelasyon & 0,566 & 0,350 & $-0,096$ \\
\hline & $\mathbf{p}$ & 0,00 & 0,00 & 0,258 \\
\hline \multirow{2}{*}{ Duygusal Bağlılık } & Korelasyon & 0,567 & 0,287 & $-0,197$ \\
\hline & $\mathbf{p}$ & 0,00 & 0,01 & 0,20 \\
\hline \multirow{2}{*}{ Normatif Bağlılık } & Korelasyon & 0,454 & 0,301 & $-0,093$ \\
\hline & $\mathbf{p}$ & 0,00 & 0,00 & 0,277 \\
\hline \multirow[b]{2}{*}{ Devam Bağlılığı } & Korelasyon & 0,490 & 0,338 & 0,006 \\
\hline & $\mathbf{p}$ & 0,00 & 0,00 & 0,940 \\
\hline
\end{tabular}

Tablo 3.17 incelendiğinde örgütsel bağlllık ile dönüşümcü liderlik arasında orta derecede güçlü, pozitif yönlü ve anlamlı bir ilişki $(0,566)$ olduğu gözlemlenmektedir. Örgütsel bağl1lığın duygusal $(0,567)$, normatif $(0,454)$ ve devam bağl1lı̆̆ $(0,490)$ boyutlarının her biri açısından da dönüşümcü liderlik algısı ile pozitif yönlü orta derecede güçlü ve anlamlı bir ilişki tespit edilmiştir. Yönetsel liderlik algısı ile örgütsel bağlılık $(0,350)$, duygusal bağl1lık $(0,287)$, normatif bağl1lık $(0,301)$ ve devam bağl1lı̆g $1(0,338)$ düzeyleri arasında düşük düzeyde, pozitif yönlü ve anlamlı ilişki tespit edilmiştir. Serbest bırakıcı liderlik algısı ile örgütsel bağl1lı $(-0,096)$ ve alt boyutları olan duygusal bağl11ık $(-0,197)$, normatif bağl1lık $(-0,093)$ arasında düşük düzeyde, negatif yönlü devam bağlılığı $(0,006)$ ile düşük düzeyde ancak pozitif yönlü istatistiksel bakımdan anlamlı olmayan bir ilişki tespit edilmiştir. Genel olarak çalışanların örgütsel bağlılık ile dönüşümcü liderlik ve yönetsel liderlik algıları arasında pozitif yönlü ve anlamlı bir ilişki olduğu gözlemlenirken, serbest bırakıcı liderlik algısı ile örgütsel bağgl11k düzeyi ve örgütsel bağl1lığın duygusal bağl1lık ve normatif bağl1lık boyutları açsından negatif yönlü ve istatistiksel bakımdan anlamlı olmayan bir ilişki tespit edilmiştir. Sonuç olarak "Banka çalışanlarının örgütsel bağlılık düzeyleri ile liderlik algıları arasında pozitif ve anlamlı bir ilişki vardır." şeklinde geliştirilen $\mathrm{H}_{1}$ hipotezi kısmen kabul edilmiştir. 


\section{SONUC}

Bu çalışmada, Konya il merkezinde faaliyet gösteren bankalarda çalışanların liderlik tarzı algıları ile örgütsel bağlılıkları arasındaki ilişki incelenmiştir. Araştırmanın sonuçları göre banka çalışanlarının liderlik algılarına yönelik dönüşümcü liderlik boyutu ve alt bileşenlerini oluşturan aktif idealleştirilmiş etki, pasif idealleştirilmiş etki, ilham motivasyon, entelektüel teşvik, bireye saygı bileşenlerinin ortalama değerlerinin yüksek olduğu tespit edilmiştir. Yönetsel liderlik boyutu ve koşulsal ödüllendirme, istisnai yönetim-aktif bileşenlerinin ortalama değerleri yüksek iken istisnai yönetim-pasif alt bileşeninin ortalama değeri düşük olduğu tespit edilmiştir. Ayrıca serbest bırakıcı liderlik boyutunun da düşük olduğu tespit edilmiştir. $\mathrm{Bu}$ bilgiler doğrultusunda banka çalışanlarının genel olarak liderlerine olan algılarının olumlu olduğu söylenebilmektedir. İstisnai yönetim-pasif bileşeninin ve serbest bırakıcı liderlik boyutunun düşük olması; bankaların faaliyetlerin yapıları itibariyle belirli kurallar çerçevesinde yürütülmesi gerekliliği, hiyerarşik kademelerin açık bir şekilde belirlenmiş olması, özel bankalar da dahil olmak üzere tüm bankaların belirli kanun ve yönetmeliklere tabii olması gibi nedenlere bağlanabilmektedir.

Ankete katılan banka çalışanlarının genel olarak örgüte bağlılıklarının düşük düzeyde olduğu tespit edilmiştir. Ancak örgütsel bağlılığın alt boyutları dikkate alındığında normatif bağlılık ve devam bağlılığının düşük olduğu sonucuna ulaş1lırken duygusal bağl1lık düzeylerinin yüksek olduğu sonucuna ulaşılmıştır.

Liderlik tarzı algıları ile örgütsel bağlılık arasındaki ilişkiyi belirlemeye yönelik yapılan analiz sonuçlarına göre örgütsel bağl1lık ile dönüşümcü liderlik arasında orta derecede güçlü, pozitif yönlü ve anlamlı bir ilişki olduğu tespit edilmiştir. Örgütsel bağl1lı̆̆ın duygusal, normatif ve devam bağlılığı boyutlarının her biri açısından da dönüşümcü liderlik algısı ile pozitif yönlü orta derecede güçlü ve anlamlı bir ilişki tespit edilmiştir. Yönetsel liderlik algısı ile örgütsel bağl1lık düzeyleri arasında düşük düzeyde, pozitif yönlü ve anlamlı ilişki tespit edilmiştir. Serbest bırakıcı liderlik algısı ile örgütsel bağlılık ve alt boyutları arasında çok düşük düzeyde, negatif yönlü ancak istatistiksel bakımdan anlamlı olmayan bir ilişki tespit edilmiştir. Genel olarak çalışanların örgütsel bağl1lık ile dönüşümcü liderlik ve yönetsel liderlik algıları arasında pozitif yönlü ve anlamlı bir ilişki olduğu gözlemlenirken serbest bırakıcı liderlik algısı ile örgütsel bağlılık düzeyi ve örgütsel bağl11ığın duygusal bağl1lık ve normatif bağl11ık boyutları açsından negatif yönlü ve istatistiksel bakımdan anlamlı olmayan bir ilişki tespit edilmiştir.

$\mathrm{Bu}$ araştırma Konya ilinde belirli bir sektörde faaliyet gösteren çalışanlar üzerinde yapıldığı için sonuçlarının genelleştirilme gücü zayıf kalmaktadır. Gelecekte yapılacak çalışmalar açısından araştırma daha büyük örneklemlerle yeniden çalışılabilir. Araştırmanın sadece belirli bir zaman dilimine ait veriler üzerinden değerlendirildiği dikkate alınması gerekmektedir. Bu araştırma sadece Konya ilinde belirli bir bölgede yapıldığı için farklı illerde benzer örneklem üzerinde veya Konya ilinde farklı sektörlerde yapılmasında fayda bulunmaktadır. Ayrıca bu araştırma belirli zaman kısıtları içerisinde yapıldığı için cevapları aranan sorular ve ileri sürülen hipotezler dikkate alındığında veri toplama metodu olarak süreli bir çalışmanın gerçekleştirilmesinin daha uygun bir yaklaşım olduğu söylenebilir. 


\section{KAYNAKÇA}

Bakan, İsmail (2009). Liderlik Tarzları ile Örgüt Kültürü Türleri Arasındaki ilişkiler: Bir Alan Çalışması. Ankara: Tisk Akademi, 4 (7), 138-172.

Bass M. Bernard (1990). From Transactional to Transformational Leadership Learning to Share to Vision. Organizational Dynamics, 18, 19-31.

Bass, Bernard M. \& Avolio, Bruce (1999). Re-Examining The Components of The Transformational and Transactional Leadership Using The Multifactor Leadership Questionnaire. Journal of Occupational And Organizational Psychology. 72, 441- 462.

Bayram, Levent (2005). Yönetimde Yeni Bir Paradigma, Örgütsel Bağlıık. Sayıştay Dergisi Eğitim Bilimler Bölümü, 59, 125-138.

Boylu Yasin, Pelit Elbeyi ve Güçer Evren (2007). Akademisyenlerin Örgütsel Bağlılık Düzeyleri Üzerine Bir Araştırma. Finans Politik \& Ekonomik Yorumlar, 44 (511), 55-74.

Cooper, David J. (2003). Leaderhip for Follower Commitment. Butterworth-Heinemann, An imprint of Elsevier Science, Linacre House, Jordan Hill, Oxford Wheeler Road, Burlington.

Çekmecelioğlu, Hülya (2006). İs Tatmini ve Örgütsel Bağlılık Tutumlarının Işsten Ayrılma Niyeti ve Verimlilik Üzerindeki Etkilerinin Değerlendirilmesi: Bir Araştırma. İş, Güç Endüstri Ilişkileri ve Insan Kaynakları Dergisi, 8(2), 153-168.

Çelik, Vehbi (2000). Eğitimsel Liderlik. Ankara: Pegem A Yayınevi Tic. Ltd. Şti.

Çöl, Güner (2004). Örgütsel Bağlılık Kavramı ve Benzer Kavramlarla İlişkisi. İş, Güç Endüstri Iliş̧kileri ve Insan Kaynakları Dergisi,6(2).

Doğan, Selen (2007). Vizyona Dayalı Liderlik. İstanbul: Kare Yayınları.

Eren, Erol (2008). Örgütsel Davranış ve Yönetim Psikolojisi. İstanbul: Beta Basım Yayım Dağııım A.Ş.

Elsenberg, Eric M.; P.R. Monge, K.I. Miller (1987), Involvement in Communication Networks as a Predictor of Organizational Commitment, Human Communication Research, 10(2), 179-201.

Ferris, Kenneth R., Nissim Aranya, (1983), A Comparison of Two Organizational Commitment Scales, Personnel Psychology, 36, 87-98.

George, M. Jennifer and Jones, Gareth, R. (2008). Understanding and Managing ORGANIZATIONAL BEHAVIOR. Pearson: Prentice Hall, Upper Saddle River, New Jersey.

Guatam, Thaneswor, V.D. Rolf, W. Ulrich (2004), Organizational Identification and Organizational Commitment: Distinct Aspects of Two related Concepts, Asian Journal of Social Psychology, 7, 301-315.

Gül Hasan (2002). Örgütsel Bağlılık Yaklaşımlarının Mukayesesi ve Değerlendirmesi. Ege Akademik Bakış Dergisi, 2(1), 37-55.

Güney, Semra (2006). Ahlaki Liderliğin Kavramsallaştırılması ve Ahlaki Yönetimde Liderliğin Rolü. Manisa: Celal Bayar Üniversitesi Yönetim ve Ekonomi Dergisi,13(1),135-148.

Jung Dong I. \& Avolio Bruce J. (2000). Opening The Black Box: An Experimental Investigation of the Mediating Effects of Trust and Value Congruence on Transformational and Transactional Leadership. Journal of Organizational Behavior, 21(8), 949-964.

MATHIEU, Joron, M.Z. Dennis (1990), A Review and Meta-analysis of the Antecedents, Correlates and Consequences of Organizational Commitment, Psychological Bulletin, 108:171-194.

Meyer, John.P. ve Allen, Natalie J. (1991). A Three Component Conceptualization at Organizational Commitment. Human Resources Management Review, 1(1), 61-89.

Meyer, John P., Allen N.J., Smith C.A., (1993), Commitment to Organizations and Occupations: Extension and Test of a Three-Component Conceptualization, Journal of Applied Psychology, Cilt:78, No:4, 538-551.

Meyer, John P. and Allen, Natalie J. (1997). Commitment in the Workplace Theory Research and Application. California: Sage Publications.

Obeng, K. and Ugboro, I. (2003). Organizational Commitment Among Public Transit Employees: An Assessment Study. Journal of The Transportation Research Forum, 57 (2), 83-98.

Ogbonna, Emmanuel and Harris, Lloyd C. (2000). Leadership Style, Organizational Culture and Performance: Empirical Evidence From UK Companies. International Journal of Human Resource Management, 11(4), 766-788. 
Özler, Derya Ergun (2010), Örgütsel Davranışta Güncel Konular, Ekin Basım Yayın Dağıtım, Bursa.

Paulin, Michèle, Ferguson, Ronald J. and Bergeron, Jasmin (2006). Service Climate and Organizational Commitment: The İmportance of Customer Linkages. Journal of Business Research, 59(8), 906-915.

Pillai, Rajnandini, Schriesheim Chester A., Williams Eric S. (1999). Fairness Perceptions and Trust as Mediators for Transformational and Transactional Leadership: A Two Simple Study. Journal of Management, 25(6), 897-933.

Robbins, Stephen ve Judge, Timothy (2012). Örgütsel Davranış (Organizational Behavior). (Çev. Edt.: Prof. Dr. İnci Erdem). İstanbul: Nobel Akademik Yayıncılık Eğitim Danışmanlık Tic. Ltd. Şti.

Sabuncuoğlu Zeyyat ve Tüz, Melek (2001). Örgütsel Psikoloji. Bursa: Ezgi Kitabevi.

Saruhan, Sadi Can ve Yıldız, Müge Leyla (2009). Çağdaş Yönetim Bilimi. İstanbul: Beta Basım Yayım Dağıtım A.Ş.

Serinkan, Celalettin (2008). Liderlik ve Motivasyon (Geleneksel ve Güncel Yaklaşımlar). Ankara: Nobel Yayım Dağıtım.

Sharma, Jai Prakash ve Bajpai, Naval (2010). Organizational Commitment and its Impact on Job Satisfaction of Employees: A Comparative Study in Public and Private Sector in India. International Bulletin of Business Administration, 9, 7-19.

Şimşek, Şerif, Akgemci, Tahir ve Çelik, Adnan (2011). Davranış Bilimlerine Giriş ve Örgütlerde Davranış. Ankara: Gazi Kitabevi.

Şişman, Mehmet (2002). Öğretim Liderliği. Ankara: Pegem A Yayıncılık.

Tannenbaum, S.I., J.E. Mathıu, E. Salas, J.A. Cannon-Bowers (1991), Meeting Trainees' Expectations: The Influence of Training Fulfillment on The Development of Commitment, Self- Efficiacy and Motivation, Journal of Applied Psychology, 6.

Weibo, Zheng, Kaur, Sharan And Jun, Wei (2010). New Development Of Organizational Commitment: A Critical Review (1960 -2009). African Journal Of Business Management, 4 (1), 12-20.

Werner, İsabel (1993). Liderlik ve Yönetim. (Çev. Vedat Üner). İstanbul: Rota Yayınları.

Wright, Patrick M. and Kehoe, Rebecca R. (2007). Human Resource Practices and Organizational Commitment: A Deeper Examination. Asia Pacific Journal of Human Resources, 46(1), 6-20.

Yiing, Lee Huey and Ahmad, Kamarul Zaman Bin (2009). The Moderating Effects of Organizational Culture on The Relationships Between Leadership Behaviour and Organizational Commitment and Between Organizational Commitment and Job Satisfaction and Performance. Leadership \& Organization. Development Journal, 30(1), 53-86.

Yousef, Darwish A. (2003). Validating the Dimensionality of Porter et al.'s Measurement of Organizational Commitment in a Non-Western Culture Setting. International Journal of Human Resource Management, 14(6), 1067-1079.

Yörük, Durmuş, Dündar, Süleyman ve Topçu, Birol (2011). Türkiye'deki Belediye Başkanlarının Liderlik Tarzı ve Liderlik Tarzını Etkileyen Faktörler. Ege Akademik Bakış Dergisi, 11 (1), 103-109.

Yukl, Gary (2010). Leadership in Organizations (7th edition). Pearson: Prentice Hall, Upper Saddle River. New Jersey.

Yüksel, Öznur (2000). Insan Kaynakları Yönetimi. Ankara: Gazi Kitapevi.

Zel, Uğur (2006). Kişilik ve Liderlik. Ankara: Nobel Yayın Dağıtım.

http://www.pearsonschoolsandfecolleges.co.uk. Erişim Tarihi: 18.03.2012. 